\title{
ANALISIS KERAGAMAN KETAHANAN GENETIK PROGENI F1 HASIL PERSILANGAN BPM 1 X RRIM 600 TERHADAP ISOLAT Corynespora cassiicola
}

\author{
Genetic Resistance Diversity Analysis of BPM 1 × RRIM 600 F1 Progenies \\ to Corynespora cassiicola Isolates
}

Fetrina OKTAVIA

Pusat Penelitian Karet

Jalan Raya Palembang - Pangkalan Balai KM 29

Sembawa, Banyuasin 30953, Sumatera Selatan

Email : fetrina_oktavia@yahoo.com

Diterima : 13 Juli 2020 / Disetujui : 21 Desember 2020

\begin{abstract}
Attack Corynespora leaf fall (CLF) disease is one of the main problems in the rubber cultivation. Various efforts to control have been done, one of them is using the superior resistant rubber clones as a planting material. The research aim to identify the resistance level of $30 \mathrm{~F} 1$ progeny that have prospective as a new superior clones that obtained from crossing of BPM $1 \times$ RRIM 600 to $C L F$ disease. The study was conducted using a completely randomized design with three replications. The resistance level is determined based on leaf wilting intensity due to sensitivity of leaves to toxin filtrate of four C. cassiicola isolates that caused loss of liquid in leaf. The results showed that leaf wilting intensity of each progeny was significantly different to each of C. cassiicola isolates. There was an interaction between the genotype of progeny with the types of isolates used in the testing. CC-GT 1 isolate had the highest virulence level among 4 isolates that used in the test. Isolates classified as haplotype 1 (CC-GT 1 and CCIRR 104) had higher virulence level than haplotype 2 (CC-RRIM 600 and CC-IRR112). Resistance level of $F 1$ progenies to $P G D C$ is very diverse whereas 4, 14, 7 and 5 progenies were classified as a very resistant, resistant, susceptible and very susceptible to CLD disease, respectively. The progenies that have high resistance have a chance to become a superior clones in the future.
\end{abstract}

Keywords: Cassiicolin; CLF disease; haplotype; Hevea brasiliensis; progeny
Abstrak

Serangan penyakit gugur daun Corynespora (PGDC) masih menjadi salah satu permasalahan utama dalam budidaya tanaman karet. Berbagai upaya pengendalian sudah dilakukan salah satunya adalah dengan penggunaan klonklon karet unggul yang resisten sebagai bahan tanam. Penelitian bertujuan untuk mengidentifikasi tingkat ketahanan 30 progeni F1 calon klon-klon unggul baru yang merupakan hasil persilangan BPM $1 \times$ RRIM 600 terhadap PGDC. Penelitian dilakukan menggunakan Rancangan Acak Lengkap dengan tiga ulangan. Tingkat resistensi ditentukan berdasarkan intensitas kelayuan daun akibat sensitivitas daun tanaman terhadap filtrat toksin empat isolat $C$. cassiicola yang mengakibatkan terjadinya kehilangan cairan pada daun. Hasil penelitian menunjukkan bahwa intensitas kelayuan daun setiap progeni berbeda nyata terhadap setiap isolat $C$. cassiicola. Terdapat interaksi antara genotipe progeni dengan jenis isolat yang digunakan dalam pengujian. Isolat CC-GT 1 memiliki tingkat virulensi yang paling tinggi diantara 4 isolat yang digunakan dalam pengujian. Isolat yang tergolong haplotipe 1 (CC-GT 1 dan CCIRR 104) memiliki tingkat virulensi yang lebih tinggi dari haplotipe 2 (CC-RRIM 600 dan CC-IRR112). Ketahanan progeni F1 terhadap PGDC sangat beragam dimana 4 progeni tergolong sangat tahan, 14 progeni tahan, 7 progeni rentan dan 5 progeni tergolong sangat rentan terhadap PGDC. Progeni yang memiliki ketahanan yang tinggi berpeluang menjadi klon-klon unggul di masa yang akan datang. 
Kata kunci : Cassiicolin; haplotipe; Hevea brasiliensis; PGDC; progeni

\section{PENDAHULUAN}

Penyakit Gugur Daun Corynespora (PGDC) yang disebabkan oleh Corynespora cassiicola merupakan salah satu penyakit penting pada tanaman karet di Indonesia dan negara-negara penghasil karet alam lainnya di Asia dan Afrika. PGDC pertama kali muncul di Indonesia sekitar tahun 1980, yang menyerang klon-klon hasil pertukaran Internasional seperti KRS 21, RRIC 103 dan RRIM 725 yang berasal dari Thailand, Sri Lanka dan Malaysia. Dalam perkembangannya, penyakit ini mulai menyerang klon-klon lain dimana jumlah klon yang terserang dan intensitas penyakit yang diakibatkannya semakin meningkat dari tahun ke tahun. Beberapa klon yang sebelumnya diketahui tahan dilaporkan menjadi terserang berat seperti klon GT 1 dan RRIM 600.

PGDC dapat menyerang tanaman karet pada berbagai tahap pertumbuhan dan perkembangan daun baik di pembibitan maupun tanaman produksi. Meskipun saat ini PGDC tidak seberbahaya SALB (South American Leaf Blight) yang menyerang hampir semua perkebunan karet di daerah asal tanaman karet di Amerika Selatan maupun penyakit gugur daun Pestalotiopsis yang outbreak menyerang perkebunan karet di Indonesia mulai tahun 2016, namun apabila tidak diatasi PGDC dapat mengakibat kerusakan parah pada tanaman karet yang mengakibatkan kerugian ekonomi mencapai 60\% (Situmorang et al., 2007). Hingga saat ini PGDC masih merupakan salah satu penyakit utama yang menyerang perkebunan karet di India (Manju et al., 2015) dan Malaysia (Mazlan et al., 2019) dan negara-negara penghasil karet lainnya termasuk Indonesia. Meskipun outbreak penyakit gugur daun Pestalotiopsis terjadi di Indonesia pada tahun 2018, pengamatan di lapangan menunjukkan bahwa intensitas serangan PGDC masih terlihat tinggi.

Secara umum perkembangan PGDC dikendalikan dengan menggunakan pestisida kimia. Selain mahal dan bersifat racun terhadap lingkungan, cara tersebut juga tidak efektif diaplikasikan pada tanaman produksi yang memiliki pohon dengan ketinggian lebih dari empat meter. Untuk mengatasi hal tersebut berbagai upaya sudah dilakukan diantaranya adalah penggunaan pestisida nabati baik yang berasal dari tanaman yang menghasilkan metabolit sekunder yang memiliki aktivitas antimikroba seperti Ageratum conyzoides dan Centrosema pubescent (Ogbebor \& Adekunle, 2005) maupun dari cendawan (Evueh et al., 2011) dan bakteri (Minh et al., 2014; Giau \& Buock, 2017) yang bersifat antagonis. Pengaturan pola penanaman klon dimana dalam suatu areal ditanam berbagai jenis klon merupakan alternatif lain pencegahan PGDC yang sudah banyak diterapkan pada perkebunan-perkebunan besar ( Situmorang et al., 2007). Namun sejauh ini semua metode tersebut masih belum efektif dalam menanggulangi permasalahan PGDC. Salah satu alternatif yang dianggap paling efektif dan ekonomis untuk menanggulangi PGDC saat ini adalah penggunaan klon-klon yang memiliki sifat ketahanan yang tinggi dan stabil sebagai bahan tanam karet. Untuk mendapatkan klon-klon karet unggul baru sebagai sumber bahan tanam, seleksi ketahanan terhadap berbagai penyakit utama harus dilakukan sebagai salah satu SOP pemilihan klon-klon anjuran.

Kerugian ekonomi akibat serangan PGDC dapat menjadi lebih serius dengan ditemukannya adanya berbagai ras isolat $C$. cassiicola yang berbeda (Atan et al., 2011). Tingkat keparahan yang diakibatkan oleh setiap ras akan berbeda. Hal ini ditemukan pada isolat $C$. cassiicola yang menyerang perkebunan karet di Malaysia, dimana terdapat dua ras isolat C. cassiicola berbeda. Ras 1 ditemukan menginfeksi klon-klon lama seperti RRIM 600 sedangkan ras 2 menyerang klon-klon baru seperti RRIM 2000 (Ismail \& Jeyanayagi, 1999). Dengan ditemukannya perubahan ketahanan klonklon yang sebelumnya tahan menjadi rentan, maka dikhawatirkan akan munculnya ras baru pada isolat tersebut di Malaysia (Nghia et al., 2010; Atan et al., 2011). Berdasarkan analisis jejaring (network analysis) menggunakan metode Reduced Median gen ITS-rDNA isolat $C$. cassiicola asal berbagai klon karet di Indonesia terlihat bahwa terdapat lima haplotipe isolat $C$. cassiicola asal tanaman 
karet Indonesia, dimana frekuensi isolat terbanyak ditemukan pada haplotipe 1 dan isolat-isolat tersebut secara umum menyerang klon-klon baru seri IRR (Indonesian Rubber Research) (Oktavia et al., 2017). Haplotipe tersebut menunjukkan kelompok ras isolat (Nghia et al., 2010), sehingga setidaknya terdapat lima kelompok ras isolat C. cassiicola yang ada di Indonesia.

Berdasarkan informasi tersebut perlu dilakukan seleksi ketahanan calon klon-klon karet unggul baru hasil persilangan menggunakan berbagai kelompok ras isolat. Pada penelitian ini dilakukan pengujian ketahanan progeni F1 hasil persilangan BPM 1 dengan RRIM 600 menggunakan tiga isolat $C$. cassiicola yang tergolong kelompok ras 1 dan 2 yang merupakan kelompok ras terbesar dari isolat C. cassiicola asal tanaman karet di Indonesia.

\section{BAHAN DAN METODE}

Penelitian dilakukan terhadap sampel daun 30 progeni $F 1$ hasil persilangan klon karet BPM 1 dengan RRIM 600 yang ditumbuhkan di dalam polybag di rumah kaca. BPM 1 merupakan klon unggul hasil pemuliaan di Indonesia yang memiliki produksi tinggi dan ketahanan yang sangat baik terhadap penyakit gugur daun. Sedangkan RRIM 600 merupakan klon introduksi dari Malaysia yang memiliki produksi tinggi namun rentan terhadap penyakit gugur daun terutama di Indonesia. Kedua klon tersebut merupakan klon populer yang digunakan dalam program pemuliaan tanaman karet di Indonesia.

Terdapat empat isolat C. cassiicola yang digunakan dalam percobaan yaitu CCGT 1, CC-IRR 104, CC-RRIM 600 dan CC-IRR 112 yang diisolasi dari klon karet GT 1, IRR 104, RRIM 600 dan IRR 112 di Kebun Percobaan Pusat Penelitian Karet, Sembawa. Isolasi-isolat dilakukan dari daun terinfeksi yang menunjukkan gejala serangan PGDC. Hasil analisis virulensi pada enam klon karet dengan berbagai tingkat ketahanan menunjukkan bahwa keempat isolat tersebut merupakan isolat yang tergolong memiliki virulensi tinggi dan tergolong kepada haplotipe 1 (CC-GT 1 dan CC-IRR 104) dan haplotipe 2 (CC-RRIM 600 dan CCIRR 112) (Oktavia et al., 2017).

\section{Uji Ketahanan Progeni F 1 terhadap Filtrat Toksin Isolat C. cassiicola}

\section{Produksi dan Aplikasi Filtrat Toksin Isolat}

Uji Ketahanan dilakukan berdasarkan aktivitas filtrat toksin cassiicolin yang dihasilkan oleh masingmasing isolat C. cassiicola. Produksi filtrat toksin dilakukan menggunakan media Czapek berdasarkan metode yang dijelaskan oleh Breton et al. (2000) dengan beberapa modifikasi terkait teknis pelaksanaan. Pengujian dilakukan menggunakan sampel daun muda berwarna cokelat (tahap pertumbuhan $\mathrm{B} 2 \mathrm{C}$ ). Untuk mendapatkan kondisi jenuh air, daun diambil dari rumah kaca dan direndam dalam air selama satu malam (16 jam). Selanjutnya $125 \mathrm{~mL}$ toksin (5 mg/L) dimasukan ke dalam baki yang ditutup dengan stryofoam yang dilubangi (diameter $3 \mathrm{~cm}$ ) dan tangkai daun dimasukan ke dalam lubang tersebut sampai terendam filtrat toksin. Gambar 1 menunjukkan tahapan perlakuan filtrat toksin pada sampel daun. Sebagai kontrol digunakan air steril sebagai pengganti filtrat toksin dan semua perlakuan diinkubasi pada temperatur ruang. Setiap perlakuan di ulang sebanyak tiga kali.

\section{Tingkat Ketahanan Progeni dan Analisis} Data

Tingkat ketahanan diukur berdasarkan estimasi kehilangan air daun akibat aktifitas filtrat toksin yang diamati berdasarkan optimasi waktu pengamatan (48 jam) setelah perendaman daun dalam filtrat toksin. Estimasi kehilangan air dihitung sebagai intensitas kelayuan daun (IKD) seperti rumus berikut (Situmorang, 2002) :

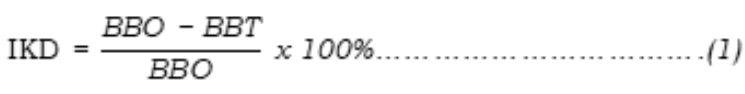

Keterangan (Remaks) :

$\mathrm{IKD}=$ persentase kelayuan daun (leaf wilting percentage)

$\mathrm{BbO}=$ berat basah sebelum perlakuan toksin (wet weight before toxin treatment)

$\mathrm{BBT}=$ berat basah setelah perlakuan toksin (dry weight before toxin treatment) 

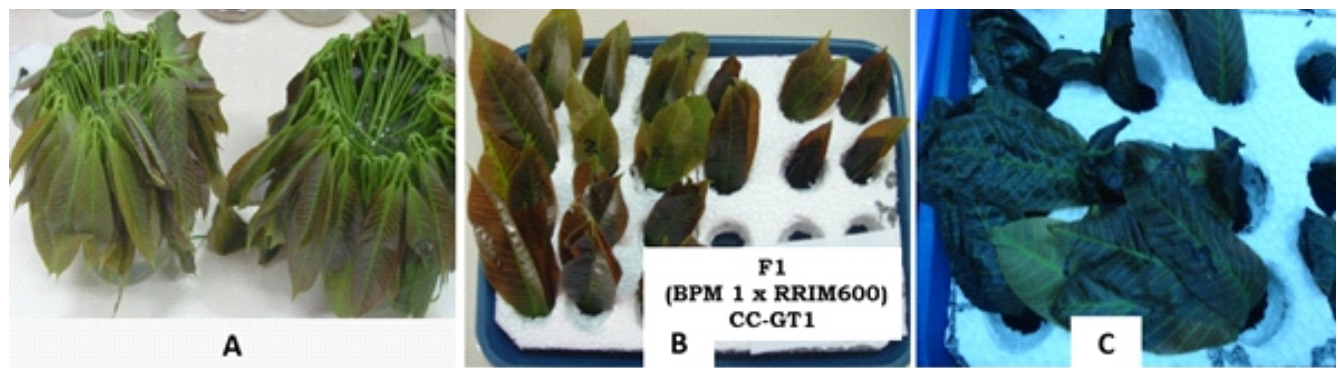

Gambar 1. Tahapan uji ketahanan progeni F1 hasil persilangan klon BPM 1 x RRIM 600 berdasarkan aktivitas filtrat toksin C. cassiicola. (A) perendaman daun dalam air selama semalam (16 jam0), (B) tangkai daun dimasukan ke dalam toksin selama 48 jam, dan (C) kondisi daun 48 jam setelah perendaman toksin

Figure 1. Stage of resistance test of 1 1 progenies of BPM $1 \times R R I M 600$ based on toxin filtrate of $C$. cassiicola. (A) soaking the leaf in water for overnight (16 hours), (B) inserted of petiols into toxin for 48 hours, and (C) condition of leaf at 48 hours after the immersion of the toxin

Tingkat ketahanan masing-masing progeni selanjutnya dikelompokkan menjadi 4 yaitu sangat tahan, tahan, rentan dan sangat rentan berdasarkan nilai standar deviasi (SD) dimana kurang dari nilai ratarata -1 SD digolongkan sebagai tanaman sangat tahan, -1 SD sampai nilai rata-rata sebagai tahan, rata-rata sampai $+1 \mathrm{SD}$ sebagai rentan dan lebih dari nilai rata-rata +1 SD digolongkan sebagai tanaman sangat rentan.

Pengelompokan progeni berdasarkan nilai intensitas kelayuan daun terhadap setiap isolat dilakukan dengan metode Euclidean Hirarchical menggunakan program DARwin6. Rancangan yang digunakan dalam penelitian ini adalah Rancangan Acak Lengkap Faktorial. Untuk melihat interaksi antara genotipe progeni dengan isolat dilakukan analisis sidik ragam (ANOVA) dua faktor (genotipe*isolat) menggunakan program SAS (Statistical Analysis System) dan apabila terdapat perbedaan nyata maka dilanjutkan dengan uji DMRT (Duncan's Multiple Range Test) $(\mathrm{P}<0,05)$.

\section{HASIL DAN PEMBAHASAN}

\section{Tingkat Ketahanan Progeni F1 terhadap Filtrat Toksin Empat Isolat C. cassiicola}

Berbagai penelitian melaporkan bahwa efektor utama infeksi $C$. cassiicola pada tanaman karet adalah fitotoksin yang disebut dengan cassiicolin (de Lamotte et al.,
2007; Breton et al., 2000; Deon et al., 2012; Deon et al., 2014; Pujade-Renaud et al., 2015; Lopez et al., 2018; Ribeiro et al., 2019). Toksin tersebut dilepaskan ke dalam sel tanaman pada tahap awal infeksi yang menyebar dengan cepat melalui pembuluh daun tanaman yang mengakibatkan terjadinya kebocoran pada membran plasma sel-sel tanaman. Pada sel tanaman hidup hal ini akan memunculkan gejala nekrosis akibat kematian sel seperti sirip ikan, sedangkan pada daun yang sudah dipetik akan menunjukkan gejala kelayuan daun (Breton et al., 2000). Tran et al. (2016) melaporkan bahwa terdapat dua QTL yang berkaitan dengan respon sel-sel tanaman terhadap filtrat toksin cassiicolin berdasarkan electrolyte leackage. Hal ini berarti bahwa pengujian menggunakan filtrat toksin cassicolin memberikan efek yang sejalan dengan penggunaan toksin murni dan pengujian menggunakan spora isolat sehingga kerentanan tanaman terhadap toksin dapat menggambarkan kerentanan terhadap isolatnya.

Pengamatan intensitas kelayuan daun (IKD) yang dilakukan terhadap 30 progeni $\mathrm{F} 1$ hasil persilangan klon BPM 1 dengan RRIM 600 menunjukkan bahwa setiap progeni memiliki respon sensitivitas yang berbeda nyata terhadap filtrat toksin masing-masing isolat (Gambar 2). Terdapat keragaman intensitas kelayuan daun yang cukup besar pada progeni F1 yang berkisar $5,2 \%$ sampai $33,4 \%$ yang ditemukan pada F1.27 terhadap toksin CC-GT 1. Setiap progeni memberikan respon yang berbeda terhadap setiap isolat karena toksin 


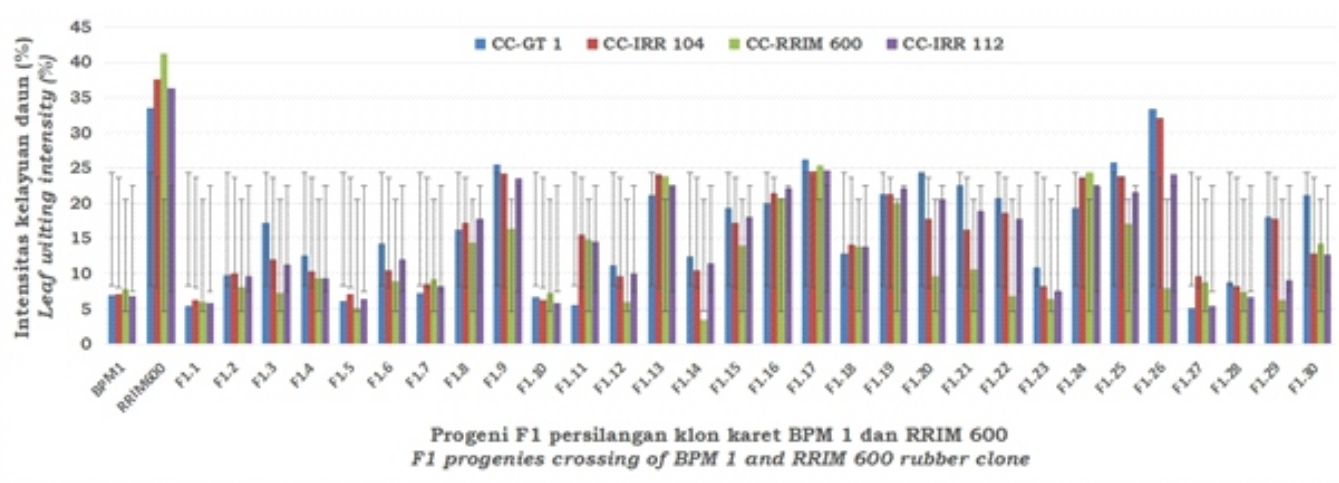

Gambar 2. Intensitas Kelayuan Daun 30 progeni F1 hasil persilangan BPM 1 x RRIM 600 terhadap filtrat toksin empat isolat C. cassiicola

Figure 2. Leaf Wilting Intensity of $30 \mathrm{~F} 1$ progenies from BPM $1 \times$ RRIM 600 to four of toxin filtrate of C. cassiicola isolates

cassiicolin merupakan toksin yang bersifat host spesific toxin (HST) yang memiliki reaksi spesifik terhadap masing-masing inang klon tanaman yang diserangnya (Deon et al., 2012).

Pada Gambar 2 juga terlihat bahwa dibandingkan dengan kedua klon tetua terlihat bahwa ketahanan progeni F1 terhadap semua isolat lebih tinggi dibandingkan dengan klon tetua RRIM 600 dan beragam terhadap tetua klon BPM 1 . Adanya keragaman respon antar progeni tersebut menunjukkan adanya perbedaan genetik antar progeni akibat proses segregasi kedua klon tetua. Beragamnya tingkat serangan penyakit sangat tergantung pada tingkat variabilitas genetik, variabilitas fenotipik dan interaksi antara keduanya, dimana suatu genotipe tahan terhadap suatu isolat namun menjadi rentan terhadap isolat lain (Breton et al., 2000; Liberei et al., 2008; Oktavia et al., 2016; Kusdiana et al., 2017). Ketahanan terhadap PGDC merupakan ketahanan yang bersifat kompleks yang diatur secara poligenik sehingga adanya variasi pada tingkat ketahanan tanaman diatur oleh gen aditif (Tan \& Tan, 1996), dan kadang kala sifat ketahanan terhadap PGDC diatur secara monogenik oleh gen-gen yang bersifat resesif (Hadi et al., 2004). Fang et al. (2016) melaporkan bahwa mekanisme pertahanan tanaman karet terhadap PGDC pada saat daun muda lebih bersifat kimia yaitu melalui pengaturan produksi metabolit sekunder seperti cyanogenic glyside ( $\mathrm{HCN})$ atau senyawa sianida yang ditandai dengan meningkatnya ekspresi gen-gen penyandi senyawa tersebut pada kondisi daun muda.

Rata-rata intensitas kelayuan daun progeni $\mathrm{F} 1$ yang disebabkan oleh filtrat toksin asal CC-RRIM 600 dan CC-GT 1 berturut-turut berkisar 12,61\% dan 16,33\% (Gambar 3). Berdasarkan hasil tersebut terlihat bahwa setiap isolat memiliki tingkat virulensi yang berbeda terhadap progeni F1 yang dianalisis. Tingkat virulensi tertinggi ditemukan pada isolat yang diisolasi dari klon GT 1 dan terendah pada isolat yang diisolasi dari klon RRIM 600. Hasil yang sama juga ditemukan pada plasma nutfah karet IRRDB 1981, dimana tanaman lebih sensitif terhadap aktivitas filtrat toksin isolat asal klon GT 1 dari pada isolat asal klon RRIM 600 (Oktavia et al., 2016) meskipun berdasarkan analisis tingkat virulensi isolat terhadap enam klon karet diketahui bahwa isolat asal klon RRIM 600 lebih virulen dibandingkan isolat asal GT 1 (Oktavia et al., 2017). Hal ini lumrah ditemukan dalam interaksi patogen dengan tanaman karena adanya kesesuaian ekspresi gen-gen virulen pada patogen dengan gen-gen resistensi pada inang. Selain itu semua isolat diisolasi dari daun tanaman karet yang menunjukkan gejala terserang PGDC dan semua isolat juga tergolong memiliki virulensi tinggi sehingga diduga mampu menginfeksi semua klon tanaman karet (Oktavia et al., 2017). Berdasarkan analisis gen cassiicolin juga diketahui bahwa isolat $C$. cassiicola asal klon RRIM 600 memiliki 
isoform yang berbeda dengan ketiga isolat lainnya (Oktavia, 2020).

Gambar 2 juga menunjukkan bahwa isolat yang tergolong haplotipe 1 (CC-GT 1 dan CC-IRR 104) memiliki tingkat virulensi yang lebih tinggi terhadap rata-rata progeni F1 hasil persilangan BPM 1 dengan RRIM 600 dibandingkan dengan isolat yang tergolong haplotipe 2 (CC-RRIM 600 dan CCIRR 112). Analisis pengelompokkan haplotipe berdasarkan sekuen gen ITS-rDNA diketahui bahwa $52,17 \%$ dari isolat $C$. cassiicola asal berbagai klon karet di Indonesia tergolong kepada haplotipe 1 dan $21,7 \%$ haplotipe 2 (Oktavia et al., 2017). Sebagian besar isolat (5 isolat) dari kelompok haplotipe 1 dan 2 isolat dari haplotipe 2 merupakan klon-klon seri IRR yang tergolong klon baru. Menurut Nghia et al., (2010), haplotipe berdasarkan sekuen gen ITS-rDNA yang merupakan constitutive gene tersebut menunjukkan kelompok ras isolat C. cassiicola. Berdasarkan analisis yang dilakukan pada isolat $C$. cassiicola asal perkebunan karet di Malaysia diketahui bahwa ras 2 banyak ditemukan menginfeksi klon-klon seri RRIM terbaru (Atan et al., 2011). Dengan ditemukannya perubahan ketahanan klon-klon yang sebelumnya tahan menjadi rentan seperti yang terjadi pada klon GT 1, maka dikhawatirkan akan munculnya ras baru pada isolat $C$. cassiicola. Berdasarkan informasi tersebut diketahui bahwa ada kemungkinan perubahan genetik pada isolat-isolat yang tergolong pada haplotipe 1 yang mengakibatkan munculnya ras-ras baru.

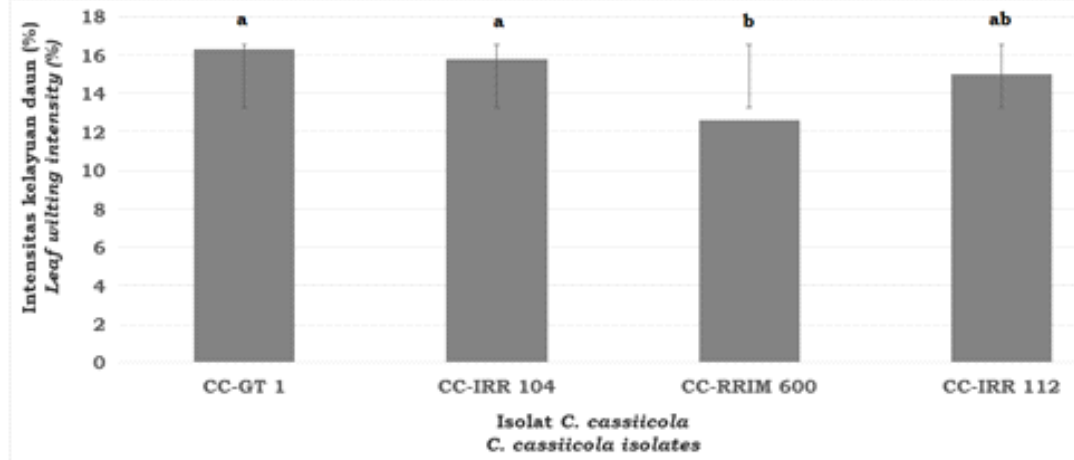

Keterangan (Remaks):

Garis pada masing-masing diagram menunjukkan standard deviasi dan diagram isolat yang memiliki huruf yang sama tidak berbeda nyata berdasarkan Uji Jarak Berganda Duncan 5\% (Line in each of diagram show standard deviation and diagram of isolate have the same letter were not significantly different based on DMRT at 5\%)

Gambar 3. Rata-rata intensitas kelayuan daun progeni F1 hasil persilangan klon karet BPM 1 x RRIM 600 akibat aktivitas filtrat toksin empat isolat C. cassiicola yang berasal dari klon karet GT 1, IRR 104, RRIM 600, dan IRR 112.

Figure 3. Average ofleaf wilting intensity of the $F 1$ progenies which was obtained from crossing of BPM 1 with RRIM 600 rubber clones caused by activity of four toxin filtrate of C. casssiicola isolates isolated from GT 1, IRR 104, RRIM 600 and IRR 112 rubber clone.

Gambar 4 menunjukkan tingkat keragaman sensitivitas progeni $\mathrm{F} 1$ terhadap empat filtrat toksin isolat C. cassiicola yang berbeda. Berdasarkan metode Hirarki Eucledean menggunakan program DARwin diketahui bahwa ketahanan progeni terhadap toksin terbagi atas dua kelompok besar pada tingkat perbedaan 68, dan kelompok besar tersebut terpisah menjadi berbagai kelompok kecil. Secara umum progeni $\mathrm{F} 1$ berada pada kelompok besar pertama bergabung dengan klon tetua BPM 1 yang memiliki ketahanan yang tinggi terhadap PGDC. Progeni F1.12 dan F1.23 memiliki tingkat ketahanan yang paling dekat terhadap filtrat toksin dan F1.10 memiliki ketahanan yang paling mendekati klon tetua BPM 1. Hanya tiga progeni F1 yang masuk ke kelompok besar kedua dimana pada kelompok tersebut terdapat tetua jantan yaitu klon RRIM 600. Hal ini berarti bahwa tingkat ketahanan progeni $\mathrm{F} 1$ yang dianalisis terhadap PGDC lebih dekat ke tetua BPM 1 yang lebih tahan dibanding tetua RRIM 600. 


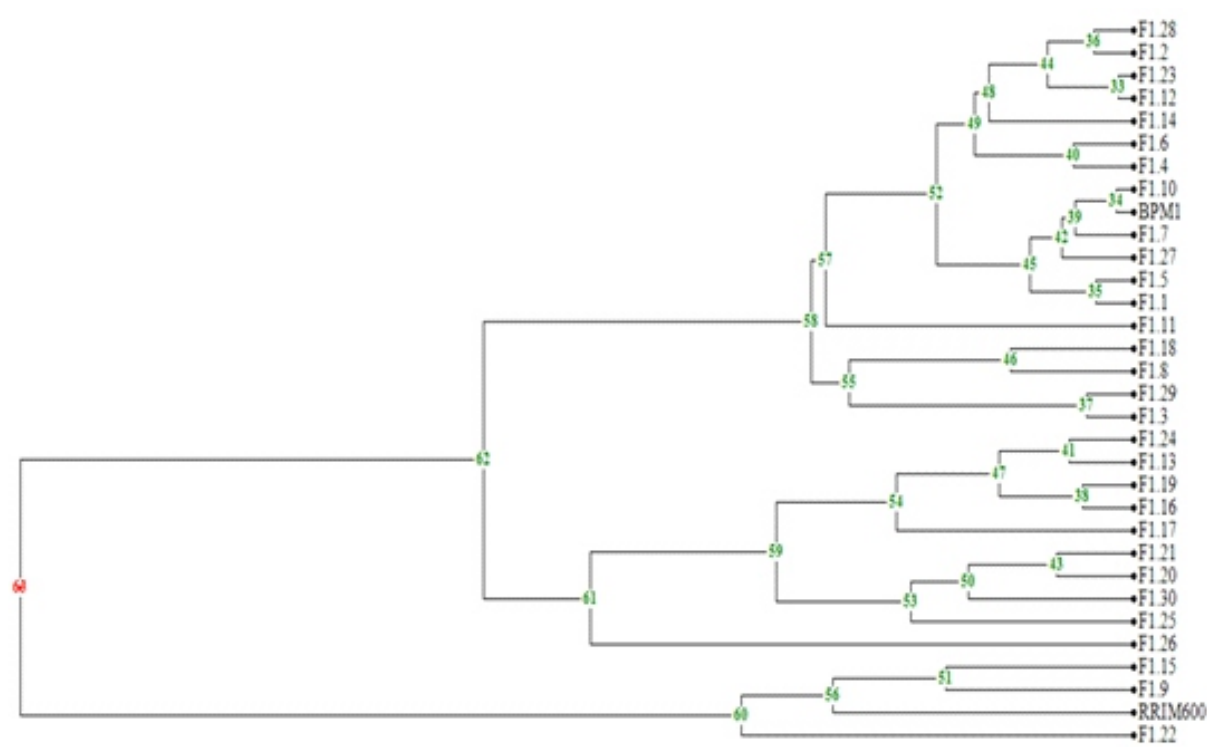

Gambar 4. Dendogram pengelompokan 30 progeni F1 hasil persilangan BPM 1 x RRIM 600 berdasarkan intensitas kelayuan daun menggunakan metode Hirarki Euclidean.

Figure 4. Clustering dendogram of $30 \mathrm{~F} 1$ progenies of BPM $1 \times$ RRIM 600 based on leaf wilting intensity using of Hirarki Euclidean method

Berdasarkan nilai standar deviasi intensitas kelayuan daun terhadap masingmasing filtrat toksin seperti yang tercantum pada Tabel 1, tingkat ketahanan progeni F1 terhadap PGDC dapat dikelompokan menjadi empat yaitu sangat tahan, tahan, rentan dan sangat rentan (Tabel 2). Berdasarkan rata-rata intensitas kelayuan daun terhadap keempat isolat tersebut maka ditentukan tingkat ketahanan masingmasing progeni $\mathrm{F} 1$ terhadap penyakit gugur daun Corynespora dimana mayoritas progeni $\mathrm{F} 1$ yaitu sebesar $47 \%$ bersifat tahan, dan $13 \%$ sangat tahan terhadap PGDC (Gambar 4). Diharapkan progeni-progeni tersebut memiliki karakter agronomi yang baik sehingga dapat dipilih menjadi klonklon karet unggul baru.

Tabel 1. Pengelompokan intensitas kelayuan daun progeni $\mathrm{F} 1$ hasil persilangan BPM 1 dengan RRIM 600 berdasarkan nilai rata-rata dan standar deviasi terhadap isolat C. cassiicola Table 1. Clustering ofleafwilting intensity of F1 progenies of BPM $1 \times$ RRIM 600 based on average and standard deviation value to C. cassiicola isolates

\begin{tabular}{lccccc}
\hline \multirow{2}{*}{$\begin{array}{c}\text { Pengelompokan } \\
\text { Clustering }\end{array}$} & \multicolumn{5}{c}{$\begin{array}{c}\text { Intensitas kelayuan daun terhadap filtrat toksin } \\
\text { Leaf wilting intensity to toxin filtrate } \\
\text { (\%) }\end{array}$} \\
\cline { 2 - 6 } & CC-GT1 & CC-IRR 104 & CC-RRIM600 & CC-IRR 112 & $\begin{array}{c}\text { Rata-rata } \\
\text { Average }\end{array}$ \\
\cline { 2 - 6 } & 16,33 & 15,79 & 12,61 & 15,00 & 14,91 \\
Rata rata & 8,15 & 7,91 & 8,10 & 7,54 & 7,30 \\
SD & 8,18 & 7,88 & 4,51 & 7,46 & 7,61 \\
Sangat Tahan & $8,18-16,33$ & $7,89-15,79$ & $4,51-12,61$ & $7,47-15,00$ & $7,61-14,91$ \\
Rentan & $16,34-24,48$ & $15,80-23,70$ & $12,62-20,7$ & $15,01-22,54$ & $14,92-22,21$ \\
Sangat Rentan & 24,48 & 23,70 & 20,71 & 22,55 & 22,21 \\
\hline
\end{tabular}


Tabel 2. Pengelompokan tingkat ketahanan 30 progeni $\mathrm{F} 1$ hasil persilangan BPM $1 \mathrm{x}$ RRIM 600 berdasarkan intensitas kelayuan daun akibat aktivitas toksin dua isolat C. cassiicola

Table 2. Resistance level clustering of $30 \mathrm{~F} 1$ progenies of BPM $1 \times$ RRIM 600 based on leaf wilting intensity caused toxin activity of two $C$. cassiicola isolates

\begin{tabular}{|c|c|c|c|c|c|c|}
\hline \multirow[b]{2}{*}{ No } & \multirow[b]{2}{*}{$\begin{array}{l}\text { Progeni } \\
\text { Progeny }\end{array}$} & \multicolumn{4}{|c|}{$\begin{array}{c}\text { Tingkat ketahanan progeni terhadap toksin } \\
\text { Resistance level of progenies to toxin }\end{array}$} & \multirow{2}{*}{$\begin{array}{l}\text { Rata-rata tingkat } \\
\text { ketahanan } \\
\text { progeni terhadap } \\
\text { toksin } \\
\text { Average of } \\
\text { progenies } \\
\text { resistance level to } \\
\text { toxin } \\
\end{array}$} \\
\hline & & CC-GT1 & CC-IRR 104 & CC-RRIM600 & CC-IRR 112 & \\
\hline 1 & BPM 1 & Sangat tahan & Sangat tahan & Tahan & Sangat tahan & Sangat tahan \\
\hline 2 & RRIM600 & Sangat rentan & Sangat rentan & Sangat rentan & Sangat rentan & Sangat rentan \\
\hline 3 & $\mathrm{~F} 1.1$ & Sangat tahan & Sangat tahan & Tahan & Sangat tahan & Sangat tahan \\
\hline 4 & $\mathrm{~F} 1.2$ & Tahan & Tahan & Tahan & Tahan & Tahan \\
\hline 5 & F1.3 & Rentan & Tahan & Tahan & Tahan & Tahan \\
\hline 6 & $\mathrm{~F} 1.4$ & Tahan & Tahan & Tahan & Tahan & Tahan \\
\hline 7 & F1.5 & Sangat tahan & Sangat tahan & Tahan & Sangat tahan & Sangat tahan \\
\hline 8 & F1.6 & Tahan & Tahan & Tahan & Tahan & Tahan \\
\hline 9 & $\mathrm{~F} 1.7$ & Sangat tahan & Tahan & Tahan & Tahan & Tahan \\
\hline 10 & F1.8 & Tahan & Rentan & Rentan & Rentan & Tahan \\
\hline 11 & F1.9 & Rentan & Sangat Rentan & Rentan & Sangat Rentan & Sangat rentan \\
\hline 12 & $\mathrm{~F} 1.10$ & Sangat tahan & Sangat tahan & Tahan & Sangat tahan & Sangat tahan \\
\hline 13 & $\mathrm{~F} 1.11$ & Sangat tahan & Tahan & Rentan & Tahan & Tahan \\
\hline 14 & F1.12 & Tahan & Tahan & Tahan & Tahan & Tahan \\
\hline 15 & $\mathrm{~F} 1.13$ & Rentan & Sangat Rentan & Sangat rentan & Rentan & Sangat Rentan \\
\hline 16 & $\mathrm{~F} 1.14$ & Tahan & Tahan & Sangat Tahan & Tahan & Tahan \\
\hline 17 & $\mathrm{~F} 1.15$ & Rentan & Rentan & Rentan & Rentan & Rentan \\
\hline 18 & $\mathrm{~F} 1.16$ & Rentan & Rentan & Sangat Rentan & Rentan & Rentan \\
\hline 19 & $\mathrm{~F} 1.17$ & Sangat rentan & Sangat rentan & Sangat rentan & Sangat rentan & Sangat rentan \\
\hline 20 & $\mathrm{~F} 1.18$ & Tahan & Tahan & Rentan & Tahan & Tahan \\
\hline 21 & F1.19 & Rentan & Rentan & Rentan & Rentan & Rentan \\
\hline 22 & $\mathrm{~F} 1.20$ & Rentan & Rentan & Tahan & Rentan & Rentan \\
\hline 23 & F1.21 & Rentan & Rentan & Tahan & Rentan & Rentan \\
\hline 24 & $\mathrm{~F} 1.22$ & Rentan & Rentan & Tahan & Rentan & Rentan \\
\hline 25 & F1.23 & Tahan & Tahan & Tahan & Tahan & Tahan \\
\hline 26 & F1.24 & Rentan & Rentan & Sangat Rentan & Rentan & Sangat rentan \\
\hline 27 & F1.25 & Sangat rentan & Sangat rentan & Rentan & Rentan & Rentan \\
\hline 28 & $\mathrm{~F} 1.26$ & Sangat rentan & Sangat rentan & Tahan & Rentan & Sangat rentan \\
\hline 29 & $\mathrm{~F} 1.27$ & Sangat tahan & Tahan & Tahan & Sangat tahan & Sangat tahan \\
\hline 30 & F1.28 & Tahan & Tahan & Tahan & Sangat Tahan & Tahan \\
\hline 31 & F1.29 & Rentan & Rentan & Tahan & Tahan & Tahan \\
\hline 32 & $\mathrm{~F} 1.30$ & Rentan & Tahan & Rentan & Tahan & Tahan \\
\hline
\end{tabular}

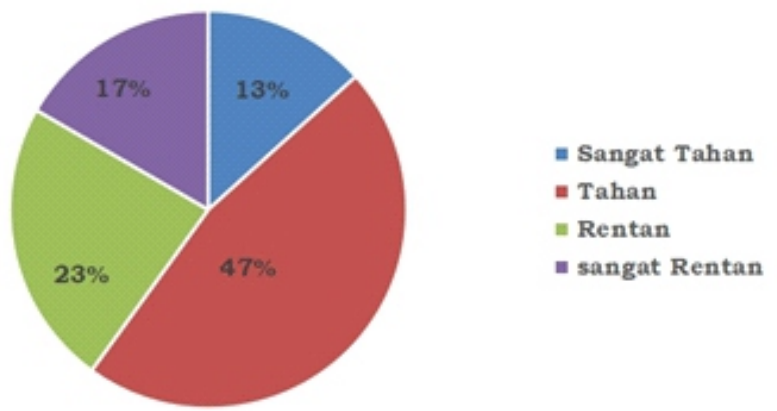

Gambar 4. Pesentase pengelompokan tingkat ketahanan progeni $\mathrm{F} 1$ hasil persilangan BPM 1 dengan RRIM 600 terhadap PGDC

Figure 4. Percentage of resistance level clustering of F1 progenies BPM 1 and RRIM 600 to CLF disease 


\section{KESIMPULAN}

Identifikasi kerentanan 30 progeni F1 hasil persilangan klon BPM 1 dengan RRIM 600 menunjukkan bahwa setiap progeni memiliki tingkat ketahanan yang berbeda nyata terhadap filtrat toksin empat isolat C. cassiicola. Dari empat isolat yang diuji terlihat bahwa isolat CC-GT 1 memiliki tingkat virulensi yang paling tinggi yang mengakibatkan tingginya intensitas kelayuan daun progeni F1. Isolat yang tergolong haplotipe 1 yaitu CC-GT 1 dan CCIRR 104 memiliki tingkat virulensi yang lebih tinggi dari pada isolat yang tergolong haplotipe 2 yaitu CC-RRIM 600 dan CCIRR112. Berdasarkan pengujian tersebut diketahui bahwa $13 \%$ progeni $\mathrm{F} 1$ hasil persilangan BPM 1 dengan RRIM 600 memiliki tingkat ketahanan yang sangat tinggi terhadap PGDC, 47\% bersifat tahan serta $23 \%$ dan $17 \%$ bersifat rentan dan sangat rentan terhadap PGDC. Progeni yang memiliki ketahanan yang baik berpeluang terpilih menjadi klon-klon karet unggul di masa mendatang.

\section{DAFTAR PUSTAKA}

Atan, S., Derapi, S., Ismail, L., \& Shukor, N. (2011). Screening susceptibility of Hevea progenies from PB 5/51 x IAN 873 to two races of Corynespora cassiicola. Journal of Rubber Research, 14(2), 110-122.

Breton, F., Sanier, C., \& d'Auzac, J. (2000). Role of cassiicolin a host-selective toxin in pathogenicity of Corynespora cassiicola, causal agent of a leaf fall disease of Hevea. Journal of Rubber Research, 3(2), 115-128.

de Lamotte, F., Duviau, M.P., Sanier, C., Thai, R., Poncet, J., Bieysse, D., Breton, F., \& Pujade-Renaud, V. (2007). Purification and characterization of Cassiicollin toxin produced by Corynespora cassiicola causal agent of the leaf fall disease of rubber tree. Journal Chromatography, 849(1-2), 357-362. https://doi.org/ 10.1016/j.jchromb.2006.10.051
Deon, M., Bourré, Y., Gimenez, S., Berger, A., Bieysse, D., de Lamotte, F., Poncet, J., Roussel, V., Bonnot, F., \& Oliver, G. (2012). Characterization of a cassiicolin-encoding gene from Corynespora cassiicola, pathogen of rubber tree (Hevea brasiliensis). Plant Science, 185-186, 227-237. https://doi.org/10.1016/j.plantsci.2 011.10 .017

Deon, M., Fumanal, B., Gimenez, S., Bieysse, D., Oliveira, R.R., Shuib, S.S., Breton, F., Elumalai, S., Vida, J.B., \& Seguin, M. (2014). Diversity of the cassiicolin gene in Corynespora cassiicola and relation with the pathogenicity in Hevea brasiliensis. Fungal Biology, $118(1), 32-47$. https://doi.org /10.1016/j.funbio.2013.10.011

Evueh, A., Okhuoya, J., Osemwegie, O., Attitalla, I., \& Ogbebor, O. (2011). Evaluation of phylloplane fungi as biocontrol agent of Corynespora leaf fall disease of rubber (Hevea brasiliensis Muell. Arg.). World Journal Fungal Plant Biology, 2(1), 1-5.

Fang, Y., Mei, H., Zhou, B., Xiao, X., Yang, M., Huang, Y., Long, X., Hu, S., \& Tang, C. (2016). De Novo transcriptome analysis reveals distinct defense mechanisms by young and mature leaves of Hevea brasiliensis (para rubber tree). Scientific Reports, 6, 33151. https://doi.org/10.1038/ srep33151

Hadi, H., Hartana, A., \& Sinaga, M. (2004). Analisis genetika pewarisan sifat ketahanan tanaman karet terhadap penyakit gugur daun Corynespora. Hayati Journal Bioscience, 11(1), 1-5.

Ismail, H., \& Jeyanangi, I. (1999). Occurrence and identification of physiological races of Corynespora cassiicola of Hevea. Proceedings of IRRDB Symposium 1999 (p. 263-272). Haikou, China: Hainan Publishing House.

Kusdiana, A.P.J., Syafaah, A., \& Oktavia, F. (2017). Resistensi tanaman karet klon IRR seri 300 terhadap penyakit gugur daun Corynespora. Jurnal Penelitian Karet, 35(2), 115 - 128. https:// doi.org/ 10.22302/ppk.jpk.v35i2.374 
Lopez,, D., Ribeiro, S., Label, P., Fumanal, B., Venisse J.S., Kohler, A., de Oliveira, R.R., Labutti, K., Lipzen, A., Lail, K., Bauer, D., Ohm, R.A., Barry, K.W., Spatafora, J., Grigoriev, I.V., Martin, F.M., \& Pujade-Renaud, V. (2018). Genome-wide analysis of Corynespora cassiicola leaf fall disease putative effectors. Front Microbiology, 9, 276. https://doi.org/10.3389/fmicb.2018. 00276

Manju, M.J., Benagi, V.I., Shankarappa, T.H., Vinod, K.K., \& Jacob, C.K. (2015). Major diseases of Hevea brasiliensis in rubber growing regions of South India. Environment \& Ecology, 33(3A), 12991302.

Mazlan, S., Jaafar, N.M., Wahab, A., Sulaiman, Z., Rajandas, H., \& Zulperi, D. (2019). Major diseases of rubber (Hevea brasiliensis) in Malaysia. Pertanika Journal of Scholarly Research Reviews, 5(2), 10-21.

Nghia, N., Kadir, J., Sunderasan, E., Abdullah, M., Malik, A., \& Napis, S. (2010). Intraspecific variability of Corynespora cassiicola inferred from single nucletide polymorphisms in ITS region of ribosomal DNA. Journal of Rubber Research, 13(4), 257-264.

Oktavia, F. (2020). Identification and diversity analysis of cassiicolin encoding gene of Corynespora cassiicola isolates from rubber tree in Indonesia. Biodiversitas Journal of Biology Diversity, 21(8), 3499-3507. https://doi.org/10.13057/biodiv/d2 1 0811

Oktavia, F., Sudarsono., Kuswanhadi., Dinarty, D., \& Widodo. (2017). Pathogenicity and rDNA-ITS sequence analysis of the Corynespora cassiicola isolates from rubber plantations in Indonesia. Emirates Journal of Food and Agriculture, 29(11), 872-883. https://doi.org/10.9755/ejfa.2017.v2 9.i11.1497

Oktavia, F., Kuswanhadi., Widodo., Dinarty, D., \& Sudarsono. (2016). Identifikasi ketahanan plasma nutfah karet IRRDB 1981 terpilih terhadap penyakit gugur daun Corynespora berdasarkan aktivitas toksin cassiicolin. Jurnal Penelitian Karet, 34(1), 35-48. https://doi.org/ 10.22302/ppk.jpk.v3 $4 \mathrm{i} 1.225$
Ogbebor, N., \& Adekunle, A. (2005). Inhibition of conidial germination and mycelial growth of Corynespora cassiicola (Berk and Curt) of rubber (Hevea brasiliensis muell. Arg.) using extracts of some plants. African Journal Biotechnology, 4(9), 996-1000.

Pujade-Renaud, V., Lopez, D., Ribeiro, S., Minh, T., Deon, M., Clement-Demange, A., Garcia, D., Drevet, P., Label, P., \& Morin, E. (2015). The effectors of Corynespora cassiicola virulence in rubber tree. Proceedings of International Rubber Confrence (p.221-224). Ho Chi Minh, Vietnam: IRRDB \& RRIV.

Ribeiro, S., Tran, D.M., Deon, M., ClémentDemange, A., Garcia, D., Soumahoro, M., Masson, A., \& Pujade-Renaud, V. (2019). Gene deletion of Corynespora cassiicola cassiicolin Cas 1 suppresses virulence in the rubber tree. Fungal Genetic and Biololgy, 129, 101-114. https: / / doi.org/10.1016/j.fgb.2019.0 5.004

Situmorang, A., Sinaga, M., Suseno, R., Hidayat, S., Siswanto., \& Darussamin, A. (2007). Sebaran penyakit gugur daun Corynespora di sentra perkebunan karet Indonesia. Jurnal Penelitian Karet, 25(1), 76-82.

Situmorang, A. (2002). Sebaran penyakit gugur daun, virulensi dan genetika Corynespora cassiicola asal sentra perkebunan karet Indonesia. [Disertasi]. Bogor: Institut Pertanian Bogor.

Tran, D.M., Clément-Demange, A., Déon, M., Garcia, D., Le Guen, V., Cle'mentVidal, A., Soumahoro, M., Masson, A., Label, P., Le, M.T., \& Pujade-Renaud, V. (2016). Genetic determinism of sensitivity to Corynespora cassiicola exudates in rubber tree (Hevea brasiliensis). PLoS ONE, 11(10), e0162807. https://doi.org/10.1371 /journal.pone.0162807

Tan, A., \& Tan, A. (1996). Genetic studies of leaf diseases resistance in Hevea. Journal of Rubber Research, 11(2), 108-114. 